\title{
Physical preparation and antioxidant supplementation for endurance racehorses
}

\author{
Preparação física e suplementação antioxidante para cavalos de enduro
}

\author{
LACERDA, Yasmim Gonçalves ${ }^{1 *}$; NASCIMENTO, Ariane Flávia do ${ }^{1}$; ALVES, \\ Felipe $^{1}$; MONTEIRO, Calebe Gallardo ${ }^{2}$; LEIRA, Matheus Hernandes ${ }^{2}$; REGHIM, \\ Lucas Silva $^{2}$
}

\author{
${ }^{1}$ Universidade José do Rosário Vellano, Programa de Mestrado em Ciência Animal, Alfenas, Minas \\ Gerais, Brasil. \\ ${ }^{2}$ Universidade Federal de Lavras, Departamento de Medicina Veterinária, Lavras, Minas Gerais, Brasil. \\ *Endereço para correspondência: yasmimlacerda@hotmail.com
}

\section{SUMMARY}

The objective of this review is to discuss aspects of the practice of endurance racing and alternatives to reduce oxidative stress in horses. Characterized by a high aerobic effort and requirement of the organic systems for maintenance of homeostasis, the endurance race is a form of sport for horses that demands great attention to the physical preparation of these animals and must be progressive, paying attention to the physiological parameters to evaluate the adaptation of the organism. To begin the preparation, the animals must be at least five years old and the duration can be on average of three years. Another factor that may be detrimental to the health and well-being of competing horses is the occurrence of oxidative stress, due to the accumulation of free radicals in the tissues, generating post-exercise muscle injuries. Antioxidant supplementation has been an alternative to this disorder. Several studies using compounds rich in antioxidant enzymes, such as superoxide dismutase (SOD), catalase (CAT) and glutathione peroxidase (GPx), demonstrate positive effects on antioxidant status, markers of oxidative stress and muscle enzymes, which may represent an improvement in performance during the exercise and recovery of animals destined to the practice of equestrian sports. Therefore, a correct physical preparation becomes crucial and antioxidant supplementation may be used to maintain the health and well-being of horses destined to the equestrian endurance practice.

Keywords: adaptation, enzymes, equine, exercise fisiology, oxidative stress

\section{RESUMO}

Objetivou-se com esta revisão discutir aspectos da prática de enduro equestre e alternativas para reduzir o estresse oxidativo em cavalos. Caracterizado por um alto esforço aeróbio e exigência dos sistemas orgânicos para manutenção da homeostase, o enduro equestre é uma modalidade de esporte para cavalos que exige grande atenção à preparação física desses animais e deve ser progressiva, atentando-se aos parâmetros fisiológicos para avaliar a adaptação do organismo. Para iniciar a preparação, os animais devem ter pelo menos cinco anos de idade e a duração pode ser em média de três anos. Outro fator que pode ser prejudicial para a saúde e o bem-estar dos cavalos concorrentes é a ocorrência de estresse oxidativo, por acúmulo de radicais livres nos tecidos, gerando lesões musculares pósexercício. A suplementação com antioxidantes tem sido uma alternativa a esta desordem. Vários estudos utilizando compostos ricos em enzimas antioxidantes, como superóxido dismutase (SOD), catalase (CAT) e glutationa peroxidase (GPx), demonstram efeitos positivos no estado antioxidante, marcadores de estresse oxidativo e enzimas musculares, o que pode representar uma melhora no desempenho durante o exercício e recuperação de animais destinados à prática de esportes equestres. Portanto, uma preparação física correta torna-se crucial, podendo-se recorrer à suplementação antioxidante para manter a saúde e o bem-estar dos cavalos destinados à prática de enduro equestre.

Palavras-chave: adaptação, enzimas, equino, fisiologia do exercício, estresse oxidativo 


\section{INTRODUCTION}

The endurance race is an equestrian sport consisting of long distance races (which can cover up to 100 miles), where competitors will encounter obstacles such as steep hills, water crossings and ditches (HODGSON et al., 2013). In these long races, where animals are challenged to the extreme stress of exercise, procedures must be carried out to ensure the animal physical safety, which is why, during competitions, animals are examined and evaluated by veterinarians before, during (at a certain distance there is a "vetstop" or "vetcheck"), so the horses can be evaluated and hydrated. If the veterinarian approves them, they continue until the next stop and after the event. What is interesting is that this type of competition is the only one where the animal can be disqualified after crossing the finish line if the veterinarian does not approve it. The animal must have predetermined normal physical conditions (e.g. heart rate and respiratory rate). Horses may not start competing before 60 months (5 years of age) at distances that cover 50 miles or more. The animal must be an adult, since the back of a young horse is much more susceptible to injury when subjected to a high pressure (HODGSON et al., 2013). Since the training should be long and intense, it is important to state that, in any sign of injuries or potential problems, the horse must stop training and be treated until recovered, the problem must be solved prior to the training program and, if it occurs during or at the beginning, pause the training until the animal can retrain. Therefore, to prepare an animal to compete in an endurance race, it is not only necessary an adequate aerobic training program, but also an anaerobic one to make the animal adequate and to complete the challenges in healthy conditions. In addition to training, it is possible to resort to dietary supplementation in order to promote reduction of inflammation and oxidative stress, allowing an improvement in the animal performance, combating muscle fatigue and speeding up recovery after exercise. Therefore, the objective of this review article is to discuss the physiological aspects and the use of antioxidant supplementation for horses destined to the practice of equestrian endurance.

\section{TRAINING PROGRAM}

Training should be progressive and may take up to 3 years to prepare a horse for a 100-mile run (HODGSON et al., 2013), as several physiological parameters are changed during competitions and training for equestrian endurance (MIYASHIRO et al., 2012). In the first stage, the horse must be trained at the basic level for long periods to ensure adaptation and decrease the chance of injury occurring, about 3 to 5 months (HODGSON et al., 2013). According to Allen et al. (2016a) field exercises have advantages over treadmill exercises, since they allow the horse to be examined in an environment similar to what it normally performs. In the second phase of training (anaerobic) there is an increase in blood lactate concentration during exercise, this condition stimulates the body to adapt to get rid of this lactate (HODGSON et al., 2013), being used in gluconeogenesis for glucose formation (BOTTEON, 2012).

It is important to focus on exercises that provide heart rate and breathing recovery. This is interesting for the development of the horse, since the recovery of the physiological parameters is an important criterion of the endurance race. (HODGSON et al., 2013). 
The use of rational training programs promotes adaptations to stress levels, providing improvement in athletic performance and reducing the possibility of injuries, especially in the musculoskeletal system. (FERRAZ et al., 2010).

The Arabian horse is the most used for this sport, because it has morphophysiological characteristics that favor resistance, such as defined and developed musculature, with a predominance of type I muscle fibers. (D'ANGELIS et al., 2005).

When subjected to intense physical effort, the animal's organism triggers a systemic effect, activating the sympathetic nervous system and the hypothalamic-pituitary-adrenal (HPA) axis, responsible for cortisol release (GRAAF-ROELFSEMA et al., 2007).

When assessing blood cortisol levels of Arabian horses submitted to treadmill test, Ferraz et al., (2010) observed elevation of plasma cortisol levels as the intensity of physical effort increased, demonstrating that such physiological variable can be used to indicate additional stressful stimulus during a training program.

\section{THE MUSCULOSKELETAL SYSTEM}

Exercise generates metabolic waste, the most important is lactate, which is produced under anaerobic conditions. For work, muscles need energy and this energy comes from glucose through a process called glycolysis, in which glucose is metabolized into pyruvate after a series of steps. When oxygen is available to the body (an aerobic condition), pyruvate is taken to the Krebs cycle, where it will be converted into more energy. However, when oxygen is limited for any reason, the body converts pyruvate to lactate, which allows glucose to decompose and thus produces energy. (NELSON \& COX, 2017). Aerobic athletic ability can be evaluated by maximal oxygen uptake $\left(\mathrm{VO}_{2} \max \right)$ (ALLEN et al., 2016a). $\mathrm{VO}_{2}$ max can be obtained by using a respiratory gas mask and a flow system (ROSE et al, 1990) or by indirect test, using equations such as expressed in the Fick: $\mathrm{VO}_{2}=Q \times(a-v) \mathrm{O}_{2}$, where $Q$ is the cardiac output in $1 \mathrm{~min}^{-1}$ and $(a-v) \mathrm{O}_{2}$ is the arterial venous oxygen content difference (WALKER et al., 2010). In horses submitted to resistance training, adaptations promoting the increase of VO2max, which consists of a rise in capillarization and mitochondrial density and changes in the main metabolic enzymes. (LEISSON et al, 2008).

There is a relationship between lactate production and removal/metabolism, represented by a velocity curve. The deflection within the lactate-velocity curve has been seen to occur in horses at a blood lactate concentration of 2-4 $\mathrm{mmol} / \mathrm{L}$ and represents the beginning of an imbalance between lactate production and its metabolism (CAMPBELL, 2011). The speed at which the blood lactate concentration reaches $4 \mathrm{mmol} / \mathrm{L}$ (VLa4), is a commonly parameter used 'artificially determined' anaerobic threshold. A decrease in VLa4 is often associated with respiratory disease. (MARE et al., 2017).

Muscles will start to "burn" fat instead of other energy sources during longdistance exercises, which is good and desirable, since fat oxidation releases less heat than other types of oxidation (HODGSON et al., 2013). According to Ishii \& Nishida (2013), the concentration of calcium $\left(\mathrm{Ca}^{++}\right)$has been shown to be responsible for the control of muscle contraction and glycogenolysis rate. Muscle fatigue during a continuous submaximal isometric contraction, performed at medium to high intensity [ $>$ $30 \%$ Maximal voluntary contraction, 
(MVC)] can be explained by changes in $\mathrm{Ca}^{++}$metabolism due to an excitationcontraction coupling failure.

In horses subjected to intense exercise, there is a raise in the activity of Nitric Oxide Synthase, signaled by an increase in the cytosolic concentration of calcium, which produces nitrogen radicals (NRs), contributing to the triggering of radical reactions that can result in tissue dysfunction and consequently muscle fatigue (BREDT, 2003). However, equine skeletal muscles have a heterogeneous composition of myofibrils, which are related to adaptations coming from athletic abilities in endurance events (GONDIM et al., 2005).

Measurement of muscle enzymes (creatine kinase $[\mathrm{CK}]$ and aspartate aminotransferase) before and after exercise provides information related to muscle damage and it may be useful to evaluate individuals with clinical or subclinical myopathy. It should be taken into account the possibility of variability in the serum $\mathrm{CK}$ activity due to the greater permeability of the cell membrane, especially if the exercise is prolonged or intense (ALLEN et al., 2016a). According to Wilberger et al. (2015) in healthy endurance racehorses, it is not uncommon to find CK levels greater than $1000 \mathrm{iu} / \mathrm{L}$, so in some cases it is difficult to interpret whether the elevation of the CK blood enzyme is a physiological or pathological case (ALLEN et al., 2016a)

\section{CARDIOVASCULAR, RESPIRATORY AND HEMATOLOGICAL SYSTEMS}

The aerobic capacity of equine athletes can be partially explained by the development of the cardiac system associated to exercise (BONOMO et al., 2014). The best horse for endurance racing, or those considered at higher fitness levels, are those who have their heart rate dropping faster (HODGSON et al., 2013). Heart growth is associated with an improvement in diastolic function, which provides speed and contraction force required for exercise. Different adaptation at the structural proteins of the sarcomeres, like actin and myosin will happen. The synthesis of these proteins will result in the increase of thickness (normally anaerobic trainings) and length of myofibrils (normally aerobic exercises) making the sarcomeres bigger (MORGAN \& BAKER, 1991).

With this improvement, the heart will be able to pump more blood at a time, resulting in a lowering at heart rate average (PERRAULT \& TURCOTTE, 2012). Historically, equine athletes have been reported to have extraordinarily large hearts. More recently, scientific evidence has confirmed associations of left ventricular size with both $\mathrm{VO} 2 \mathrm{max}$ and race performance (ALLEN, et al., 2016a). In a study, Dumont et al. (2010) found an average heart rate of 35.85 beats per minute (bpm) at rest and an average of $53.78 \mathrm{bpm}$ post-exercise in purebred Arabian horses submitted to prolonged exercise endurance race. The size of the heart varies according to the weight of the animal. In horses, this value is 0.8 to $1.0 \%$ of body weight in purebred horses, and in other breeds it is 0.6 to $0.8 \%$. The position of the cardiac apex of horses is 2 to $3 \mathrm{~cm}$ in respect to the sternum. (GOMES, 2005).

Muscles will have an increase in the number of capillary vessels as a result of training. This development of vessels allows the blood to circulate more through the muscles. This prolonged time of contact, also increased by long time exercises, allows the muscle to have a greater exchange with the blood (e.g. greater uptake of glucose and free fat acids and removal of lactate and carbon dioxide from the muscle) (HODGSON et al., 2013). 
Knowing the details of the respiratory function of horses is essential for an adequate evaluation of this system. Even in healthy horses, the respiratory system may constitute a limiting factor to the maximum performance of equine athletes (WATANABE et al., 2009). From the calculation of the maximum oxygen consumption $\left(\mathrm{VO}_{2} \max \right)$ it is possible to evaluate the aerobic capacity of an individual and it becomes an important predictor of the performance as the competition distance increases (ALLEN et al., 2016b).

Also responsible for the increases in $\mathrm{VO}_{2} \max$ are the red blood cells, which also have an increase in their number. The reflection of this is better thermoregulation and oxygen distribution in body tissues (HODGSON et al., 2013). Oxygen can only be transported due the linked integration between lungs, heart, circulation and muscle. According to Wagner (2005) the path of the oxygen during the exercise is "ventilation and alveolar-capillary diffusion (in the lung), hemoglobin binding, blood flow (in the circulation), and capillarymitochondrial diffusion (in muscle)".

\section{SUPLEMMENTATION ANTIOXIDANT}

When subjected to intense exercise, the animal body tends to consume more oxygen $\left(\mathrm{O}_{2}\right)$ (SATO et al., 2015). Oxygen molecules have a strong tendency to receive an electron, due to their electron configuration, forming the superoxide $\left(\mathrm{O}_{2}^{-}\right)$radical. This radical, by receiving one more electron and two hydrogen atoms, through a process called dismutation, forms hydrogen peroxide $\left(\mathrm{H}_{2} \mathrm{O}_{2}\right)$ (SCHNEIDER \& OLIVEIRA, 2004), increasing the production of free radicals in the musculature, causing oxidative stress. From this reaction, accelerated muscle fatigue occurs, causing damage to muscle fibers (SATO et al., 2015).

Some enzymes are released into the bloodstream, after exercise, when muscle fibers are damaged. Among them, creatine kinase (CK), aspartate aminotransferase (AST) and lactate dehydrogenase (LDH) are used to indicate muscle damage (THOMASSIAN et al., 2007). In a study, Sato et al. (2015) observed a reduction in serum levels of creatine kinase (CK) and isoenzyme-5 lactate dehydrogenase (LDH-5) activity in horses submitted to exercise receiving continuous daily supplementation of astaxanthin $(75 \mathrm{mg})$ and L-carnitine $(3,000 \mathrm{mg})$ for 8 weeks. This prevented the appearance of clinical signs of rhabdomyolysis, a muscular degenerative pathological process that occurs commonly after an episode of intense physical exercise, due to the excess of lactate in the musculature.

The natural antioxidant defense system fights against oxidative stress in part due to the action of enzymes: superoxide dismutase (SOD), catalase (CAT) and glutathione peroxidase (GPx) (SCHNEIDER \& OLIVEIRA, 2004), which are involved in the removal of $\mathrm{O}_{2}^{-}$and $\mathrm{H}_{2} \mathrm{O}_{2}$ (JIMÉNEZ et al., 2005).

In equine athletes, several experiments with antioxidant suplemmentation provided evidence that exercise-induced disorders could be partially avoided. Many antioxidant compounds that are present in the diet may have health benefits and there is evidence that the consumption of these products causes a reduction in the expression of different biomarkers of oxidative stress (NOTIN et al., 2010)

Mélo et al. (2016) confirmed that supplementation with a mixture of polyunsaturated fatty acids and vitamin E over an eight-week period was able to increase the concentration of 
biomarkers GPx, SOD in horses under and in training, reducing the effects of oxidative stress.

Moffarts et al. (2005) using a mixture of vitamins and trace elements (ascorbic acid: $11500 \mathrm{mg}$, alpha-tocopherol acetate: $7000 \mathrm{mg}$, beta-carotene: 500 mg, copper: $187 \mathrm{mg}$, zinc: $769 \mathrm{mg}$ and selenium: $7 \mathrm{mg}$ ), administered on purebred horses over a period of three months, found an improvement in antioxidant capacity and GPx activity.

Williams et al. (2004) reported an increase in the antioxidant status of endurance race horses supplemented with lipoic acid and vitamin E. Notin et al., (2010) demonstrated that oral supplementation with cantaloupe melon extract (CME) in the amount of $500 \mathrm{IU} /$ day could limit the increase in plasma CK, reducing the oxidative stress in Standardbreds horses.

Although several studies have been conducted to evaluate antioxidant status and other metabolites and markers of oxidative stress in exercise horses, there is a long way to go in order to understand the great variation of results with or without antioxidant supplementation (WILLIAMS, 2016).

Understanding the exercise physiology is crucial for proper training of endurance horses. For this to occur, a qualified professional should evaluate the physiological variables of all systems, verifying if these animals are correctly adapted to the practice of exercises and if they have fitness for this sport.

Experiments demonstrate that supplementation with antioxidant compounds can provide better health and well-being to animals during highendurance sports. However, attention should be paid to the concentration of the compounds offered to such animals, so that they are not supplemented above the appropriate level causing undesirable effects. maintenance

In general, studies that evaluate antioxidant supplementation for equine athletes are performed on animals of different ages, races and sex. Different supplements concentrations are used, showing very variable results. Thus, more studies are necessary aiming to produce supplements that provide satisfactory results in the fight against oxidative stress in endurance horses.

\section{REFERENCES}

ALLEN, K.J.; ERCKWESTERGREN, E.; FRANKLIN, S.H. Exercise testing in the equine athlete. Equine

Veterinary Education, v.28, n.2, p.8998, 2016.

BONOMO, C.C.; MICHIMA, L.E.; MIYASHIRO, P.; FERNANDES, W.R. Avaliação ecocardiográfica do desenvolvimento cardíaco de cavalos atletas: comparação entre atividades físicas distintas. Pesquisa Veterinária Brasileira, v.34, n.9, p.923-927, 2014.

BOTTEON, P. Lactato na medicina veterinária - atualização conceitual.

Revista Brasileira de Medicina Veterinária, v.34, n.4, p.283-287, 2012.

BREDT, D.S. Nitric oxide signaling specificity - the heart of the problem. Journal of Cell Science, v.116, p.9-15, 2003.

CAMPBELL, E.H. Lactate-driven equine conditioning programmes. Veterinary Journal, v.190, n.2, p.199-207, 2011. 
D’ANGELIS, F.H.F.; FERRAZ, G.C.; BOLELI, J.C.; LACERDA-NETO, J.C.; QUEIROZ-NETO, A. Aerobic training, but not creatine supplementation, alters the gluteus medius muscle. Journal of Animal Science, v.83, p.579-485, 2005.

DUMONT, C.B.D.S.; LEITE, C.R.; MORAES, J.M. D.; ALVES, R.D.O.; GODOY, R.D.F.; LIMA, E.M.M.D. Parâmetros eletrocardiográficos de equinos Puro Sangue Árabe submetidos a exercício prolongado de enduro. Ciência Rural, v.40, n.9, 2010.

FERRAZ, G.D.C.; TEIXEIRA NETO, A.R.; PEREIRA, M.D.C.; LINARDI, R.L.; LACERDA NETO, J.C.D.; QUEIROZ NETO, A.D. Influência do treinamento aeróbio sobre o cortisol e glicose plasmáticos em equinos. Arquivo Brasileiro de Medicina Veterinária e Zootecnia, v.62, n.1, p.23-29, 2010.

GONDIM, F.J.; MODOLO, L.V.; CAMPOS, G.E.; SALGADO, I. Neuronal nitric oxide synthase is heterogeneously distributed in equine myofibers and highly expressed in endurance trained horses. Canadian Journal of Veterinary Research, v.69, n.1, p.46, 2005.

\section{GOMES, O.M. Fisiologia} cardiovascular aplicada. Belo Horizonte: EDICOR, 2005. p.63.

GRAAF-ROELFSEMA, E.de; KEIZER, H.A.; VAN BREDA, E.; WIJNBERG, I.D.; VAN DER KOLK, J.H. Hormonal responses to acute exercise, training and overtraining a review with emphasis on the horse. Veterinary Quarterly, v.29, n.3, p.82-101, 2007.

HODGSON, D.R.; MCKEEVER, K.H.; MCGOWAN, C.M. The athletic horse: principles and practice of equine sports medicine. $2^{\text {th }}$ ed. Missouri: Elsevier Health Sciences, 2013.
ISHII, H.; NISHIDA, Y. Effect of lactate accumulation during exercise-induced muscle fatigue on the sensorimotor cortex. Journal of Physical Therapy Science, v.25, n.12, p.1637-1642, 2013.

JIMÉNEZ, M.H.; CERRILA, M.E.O.; PERALTA, M.C.; HARO, J.G.H.; DÍAZCRUZ, A.; PERRUSQUÍA, R.G. Estrés oxidativo y el uso de antioxidantes en animales domésticos. Interciencia: Revista de Ciencia y Tecnología de América, v.30, p.728-734, 2005.

LEISSON, K.; JAAKMA, Ü.; SEENE, T. Adaptations of equine locomotor muscle fiber types to endurance and intensive high speed training. Journal of Equine Veterinary Science, v.28, n.7, p.395-401, 2008.

MARE, L.; BOSHUIZEN, B.; PLANCKE, L.; DE BRUINJN, M.; DELESALLE, C. Standardized exercise tests in horses: current situation and future perspectives. Vlaams Diergeneeskundig Tijdschrift, 86, 6372, 2017.

MÉLO, S.K.M.; DINIZ, A.I.A.; DE LIRA, V.L.; MUNIZ, S.K.O.; DA SILVA G.R.; MANSO, H.E.C.C.C.; MANSO FILHO, H.C. Antioxidant and haematological biomarkers in different groups of horses supplemented with polyunsaturated oil and vitamin E. Journal of Animal Physiology and Animal Nutrition, v.100, p.852-859, 2016.

MIYASHIRO, P.; MICHIMA, L.E.D.S.; BONOMO, C.C M.; FERNANDES, W.R. Concentração plasmática de cortisol decorrente do exercício físico em cavalos de enduro. Ars Veterinaria, v.28, n.2, p.85-89, 2012. 
MOFFARTS, B.de; KIRSCHVINK, N.; PINCEMAIL, J.; LEKEUX, P. Effect of oral antioxidant supplementation on blood antioxidant status in trained thoroughbread horses. Veterinary Journal, v.169, p.65-74, 2005.

MORGAN, H.; BAKER, K. Cardiac hypertrophy: mechanical, neural, and endocrine dependence. Circulation, v.83, p.13-25, 1991.

NELSON, D. L.; COX, M. M. Lehninger Principles of Biochemistry/Seventh Edition. Freeman, W. H. \& Company, 2017.

NOTIN, C.; VALLON, L.; DESBORDES, F.; LELEU, C. Oral supplementation with superoxide dismutase in Standardbread trotters in training: a double-blind placebocontrolled study. Equine Veterinary Journal, v.42, n.38, p.375-381, 2010.

PERRAULT, H.; TURCOTTE, R. A. Exercise-Induced Cardiac Hypertrophy Fact or Fallacy? Sports Medicine, v.17, p.288-308, 2012.

ROSE, R.J.; HODGSON, D R.; BAYLY, W.M.; GOLLNICK, P.D. Kinetics of $\mathrm{VO} 2$ and $\mathrm{VCO} 2$ in the horse and comparison of five methods for determination of maximum oxygen uptake. Equine Veterinary Journal, v.22, n.9, p.39-42, 1990. Suppl.

SATO, F.; OMURA, T.; ISHIMARU, M.; ENDO, Y.; MURASE, H.; YAMASHITA, E. Effects of Daily Astaxanthin and L-Carnitine Supplementation for Exercise-Induced Muscle Damage in Training Thoroughvread Horses. Journal of Equine Veterinary Science, v.35, p.836$842,2015$.
SCHNEIDER, C.D.; OLIVEIRA, A.R. Radicais livres de oxigênio e exercício: mecanismo de formação e adaptação ao treinamento físico. Revista Brasileira de Medicina do Esporte, v.10, p.303-313, 2004.

THOMASSIAN, A.; CARVALHO, F.de; WATANABE, M.J.; SILVEIRA, V. F.da; ALVES, A.L.G.; HUSSNI, C.A.; MELLO NICOLLETI, J.L. de. Atividades séricas da aspartato aminotransferase, creatina quinase e lactato desidrogenase de eqüinos submetidos ao teste padrão de exercício progressivo em esteira. Brazilian Journal of Veterinary Research and Animal Science, v.44, n.3, p.183-190, 2007.

WAGNER, P.D. Why doesn't exercise grow the lungs when other factors do? Exercise and Sport Sciences Reviews, v.33, p.3-8, 2005.

WALKER, A.; ARENT, S. M.; MCKEEYER, K. H. Maximal aerobic capacity (VO 2max) in horses: a retrospective study to identify the agerelated decline. Comparative Exercise Physiology, 6(4), 177-181, 2009.

WATANABE, M.J.; SILVEIRA, V.F.da; MACHADO, L.P.; YONEZAWA, L.A.; KOHAYAGAWA, A.; THOMASSIAN, A. Aplicação da espirometria durante teste padrão de exercício progressivo em esteira para avaliação da troca gasosa respiratória de equinos da raça Árabe. Archives of Veterinary Science, v.14, n.1, 2009.

WILBERGER, M.S.; MCKENZIE, E.C.; PAYTON, M.E.; RIGAS, J.D.; VALBERG, S.J. Prevalence of exertional rhabdomyolysis in endurance horses in the Pacific Northwestern United States. Equine Veterinary Journal, v.47, n.2, p.165-170, 2015. 
WILLIAMS, C.A.; KRONFELD, D.S.;

HESS, T.M.; SAKER, K.E.; HARRIS, $P$. Lipoic acid and vitamin $\mathrm{E}$ supplementation to horses diminishes endurance exercise induced oxidative stress, muscle enzyme leakage, and apoptosis. In: LINDNER, A. (Ed.). The elite race and endurance horse. Oslo, Norway: CESMAS, 2004a. p.105-119.

WILLIAMS, C.A. The effect of oxidative stress during exercise in the horse. Journal of Animal Science, v.94, n.10, p.4067-4075, 2016.

Receipt date: $21 / 08 / 2017$

Approval date: 19/02/2018 